Eradication of poverty through community economic development using micro financing: Lessons learned from Grameen Bank Bangladesh

\author{
Rouf, Kazi Abdur $\bowtie$ \\ York Center for Asian Research Center (YCAR), York University, Canada (Kaziabdur56@hotmail.com)
}

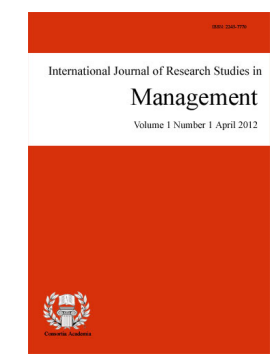

ISSN: 2243-7770 Online ISSN: 2243-7789

OPEN ACCESS

\begin{abstract}
Community Economic Development (CED) model is an alternative socio-economic development approach that provokes for the local economic development in order to eradicate poverty among the disadvantaged people in the community. P. Boothroyd and H. Davis (1993) in their article talk about the "Community Economic Development: Three Approaches" where they narrates three different frameworks of community economic development. Although these three frameworks of CED emphasis on the holistic economic community development, each CED approach/framework has a special feature that emphasizes on particular socio-economic elements pointed by capital letters $\mathrm{Ced}$, cEd, and ceD based on each community development project's nature and type. This paper is an effort to explore the application of CED- three approaches in the contexts of Canada and Bangladesh. The paper also deeply looks at Grameen Bank activities in Bangladesh, K-Net Canada as case studies; and analyzes GB activities and K-Net Canada activities in the lens of the CED- Three approaches designed by P. Boothroyd and H. Davis (1993).
\end{abstract}

Keywords: community development; community economic development (CED); community organizing; feminization of poverty; Grameen Bank micro-credit 


\section{Eradication of poverty through community economic development using micro financing: Lessons learned from Grameen Bank Bangladesh}

\section{Introduction}

Micro-credit plays a vital role in attaining the Millennium Development Goals (MDGs) to eradicate poverty in many countries. The Grameen Bank (literally 'village bank') of Bangladesh is a notable example of using micro-credit to facilitate community economic development in Bangladesh. The group based micro-credit Grameen America program even successful in USA. It has had a significant impact on poverty alleviation as well as fostering local citizen empowerment in Bangladesh and many other countries in the world. The micro-credit institutions (MFIs) have managed to both increase local economic activity and build community savings through their highly successful and world-renowned projects. This essay reflects upon a number of experiences, as a result of the author's hands-on exposure to micro-finance management through his years of work at the Grameen Bank and many other micro-credit projects in different countries. The paper also explores the various concepts of poverty, feminization of poverty, community economic development and micro financing in the context of Bangladesh. Finally, it will explore how Grameen Bank fits the concept of Community Economic Development (CED) formulated by Boothroyd, P. and Davis, H. (1993) in their article "Community Economic Development: Three Approaches".

According to the World Bank (2010), poverty is a shortage of income that makes people vulnerable to chronic hunger and disease. Cheston, S., and Kuhn, L. (2002) and Yunus (2007) mention that poverty victims are suffering from to feed them three meals a day. Poor people are victims of living in decent house; they do not have money to buy healthcare. Over 1.3 billion people have an income of less than $\$ 1$ (US) per day, and 3 billion people are below the poverty line. This is a massive tragedy of human suffering and loss of potential. Seventy percent of rural women in Bangladesh live below the poverty line, which is significantly higher than the overall national average of fifty-one percent. The rate of unemployment in Bangladesh is a staggering 52.5\% (Human Rights Report, 2005). The United Nations Human Development Index (HDI) identifies a lack of health care, education and social involvement of poor people in Bangladesh. Furthermore, there are serious inadequacies with respect to environmental conditions, religious and political freedom and basic human needs there, although situation improving gradually.

\subsection{The Situation in Bangladesh}

Currently, Bangladesh has 156 million people in an area of 147,570 square kilometers. Half of the population is female (Bangladesh Profile, 2014). The density of the population is 763 per square kilometer and individual's per capita income is $\$ 2100$ (US). Only $30 \%$ of the population has access to basic health services and $76 \%$ of all households are deficient in calorie intake (CIDA 2001: Gender profile Bangladesh). There is a strong link between extreme poverty and women as a result of a lack of basic human rights for women in Bangladesh.

The feminization of poverty is increasing day by day at an alarming rate (Human Right Report, 2013). Women are regularly objectified and treated as commodities. Female labor force participation in paid employment is limited. They are forbidden to work outside of the home due to prevailing social norms. Wives are not to travel far from the home and are restricted to performing stereotypically acceptable female labor such as agriculture and seed preservation. The most significant human rights problems were arbitrary arrests, regulation of online speech, and poor working conditions and labor rights (Human Rights Report Bangladesh, 2013)

This feminization of poverty in Bangladesh has strong historical roots. For 200 years, the country was under misogynistic British rule. Later under Pakistani rule, the exploitation continued. Governments discouraged 
female egalitarianism and worked actively to destroy self-sufficient communities resulting in reduced literacy. Natural calamities, capitalism, globalization and structural adjustment policies (SAP) have all had a negative impact on rural women in Bangladesh. However, several individual NGO initiatives and cooperatives were found to have rescued these vulnerable women from their predicament. Nonetheless, many of these initiatives failed to address poverty directly, due to a lack of support from the state.

People resented a lifestyle which only focused on hard labor and despair. Access to formal credit from financial institutions, to improve their situation, was impossible since such institutions required collateral, which an extremely poor person could not provide (Yunus, 2007). All through their lifetime, they have learned only to work for others, which contributed to low self-esteem and left no hope for future. In such deprivation of banking facilities, the Grameen Bank group-based micro-credit services at the door step of poor has provided a great ray of hope to rural marginalized people in Bangladesh.

\subsection{Significance of the study}

Individualistic norms and values have started from the pre-industrial and industrial capitalistic society, but individualistic economic divide polarization process increases in the post- industrial period through emerging giant cities and globalization. This socioeconomic and cultural polarization process creates community divide, uneven rural-urban divide, socio-economic divide, cultural divide, and environmental destructions in the society. Giant cities and globalization overexploited natural resources and human resources without giving return to earth and community. Cities have become so large that comparatively simple services and agencies have posed problems. Even technology unable to solve social and economic problems rather technology increasingly create socio-economic gap, injustice, anti-altruism unethical individualistic values and norms in the unsatisfactorily. The financial crisis of 2008-2009 grows from the same root-a fundamental flaw in the theoretical construct of capitalism (Yunus, 2013).

This new capitalistic industrialized urbanizing society not only looks for profits at the expense of human exploitation, social, economic, cultural and environmental exploitation and injustice in the society, but also swipes community communal altruistic values, cooperative norms, principles, human common wellbeing. As a result, increase poverty, unemployment, financial artificial crisis; exploit human chief labor, gender discrimination, racism and stereotyping individual capability in the society. Consequently resources and power concentrated in the hands of few dominating people. Mass people of the society are less wealthy and suffering from miseries across the world particularly in Bangladesh. However, the community micro-credit Grameen Bank banking services is a community economic program (CED) in Bangladesh that assists poor people to engage in small businesses to earn income and make networking among them. Now the Grameen Bank group-based micro-credit is popular and effective all over the world even in the developed countries.

\section{Community and Community Economic Development (CED)}

Before discussing the relationship between micro finance and community economic development (CED), it is important to define community and community economic development. A community is a group of people who know each other personally and who plan together towards a common goal, and work to overcome adversity (Shragge, 1997). It is an alternative economic program that is working for to solve problems that community people ate facing-unemployment, poverty, job loss, and environmental degradation. According to Christenson, Fendley, and Robinson (1994), a community is defined as people that live within a geographically bounded area who interact socially, have one or more ties with each other and the place in which they live (p.8). This is done while maintaining social networks through intense ties, social interaction and an identification with the community. However, there are many communities that interact with and network among themselves without living in a particular geographical area. For example, Muslims may interact about issues from different places via the Internet. 
Community development is a living process that strives for creating communal identity and changing the dominating power structure of the society. Community communal values can minimize power struggle and develop trust among community people instead create competition and conflict among people in the society. Hence promotion of community communal norms, values and practices of caring each other and helping each other is essential and important in the socio-economic cultural divide modern society. It is required to understand meaning of community and community development; know about strategies of community organizing, community capacity building and community planning steps/process. The promotion of community communal norms, values and practices of caring each other and helping each other is important in the socio-economic cultural divide society. This knowledge can help community people organize themselves to use their community resources, create opportunities for local initiatives, feeling of "We" instead "I". These processes assist people engaging in community development activities and uphold deepening community solidarity communal values in their life. The paper below talks about the meaning of community economic development (CED).

Eric Shragge (1997) defines CED the in following way: "CED is a cooperative attempt by local people to take control of the socioeconomic destiny of the community to respond to local needs" (p. 12). It is an attempt is to democratize the economic lifestyle of the neighboring communities (p. 103). In other words, CED is a socially directed approach in which individual groups devote their efforts towards meeting the basic needs of the others in the community. These necessities are determined by deliberate allocation of scarce resources. Here local communities work together at setting up businesses and promoting their own interests through economic expansion. Here the definition of economy serves all CED approaches (Ced, cEd, and ceD) can be given as a system of human activity directed to meeting human basic needs that is determined by deliberate allocations of scarce resources" (Boothroyd \& Davis, 1993, p. 230).

Community Economic Development (CED) is a field of study that actively elicits community involvement when working with government, and private sectors to build strong communities, industries, and markets. Community Economic Development is a multifaceted comprehensive approach to community change that is not limited to just poverty programs, nor is it synonymous with industrial recruitment. Community Economic Development is not an attempt to exploit resources to yield the maximum economic return (Schaffer, Deller, \& Marcouiller (2004). Community Economic Development is often involved in a process of building social enterprises that are the component of social economy. CED organizations sometimes called the NGOS, third sector, a community-based social enterprise is a partnership between government agencies, small to medium enterprises, large national or transnational corporations and the not-for-profit sector, and aims for social, economic and/or environmental outcomes that none of these agencies could achieve for and by themselves. $\mathrm{K}-\mathrm{Net}$ Canada is a CED program in Canada is providing healthcare information services Northern Canada. The Toronto Community Housing Corporation (TCHC) is housing for the low-income people in Toronto build by the Government of Canada now managed by private sector in Toronto. Asrayon Prokalpa (housing for landless) is a CED program in Bangladesh supported by the Government of Bangladesh and managed by Habitat, an NGO in Bangladesh. The grameen bank community banking is a CED program in Bangladesh that works for poor people to make them an economic actor and a social actor in the community in Bangladesh.

Micro financing is a small financing system, whereby, interested private entrepreneurs borrow money for running their own sustainable small business ventures. Micro financing is run by NGOs all over the world. Micro financing is working with local currency to provide banking services for the poor to create self-employment among them through involving them in income generating schemes; this CED micro-financing service helps poor earn income for meeting their basic needs and building the community local economy. It also mobilizes small deposits and community savings which are used to invest in community planning.

Bangladesh is a non-welfare state and a largely rural society where social safety nets programs and services are needed. The Government of Bangladesh has been implementing a 'Cooperative Village' approach as a means to achieve integrated rural development through the establishment of the Bangladesh Rural Development Board (BRDB). In 1972, it established the Mahilla Samitty (Women's Cooperatives) to encourage women to work 
independently from men, acquire literacy skills and engage in planned family planning as well as to develop leadership skills for their representation in the local community. However, the programs tend to exclude the poorest women in Bangladesh, as they are unable to pay the weekly membership fees, the equivalent to one Canadian penny. Kabeer, a social scientist of Bangladesh also mentions the systemic denial of women's autonomy in Bangladesh (Kabeer, 1983, p. 6). In this situation Grameen Bank (GB) provides group-based mini cooperative micro financing services to the poorest rural women that generate a ray of hope to them. GB provides them with the opportunity, through microfinance, to start and run their own businesses.

Grameen Bank operates nationwide through 2185 branches. The repayment rate has been highly satisfactory (97\%) since 1979. The majority of them (97.9\%) are women borrowers. The Bank serves a total of 8.6 million borrowers through 130, 000 rural landless associations in 70,370 villages in Bangladesh. Total loan disbursement is $\$ 16.65$ billion since its inception. Of them $\$ 14.00$ billion has been repaid. Current borrower savings are $\$ 2.2$ billion. To date, its monthly loan disbursement is $\$ 58.00$ million and $100 \%$ loans financed from borrowers deposits (Grameen Bank Updates, 2014). It has 18,000 staffs working at the village level nationwide. GB has not been receiving grants from outside sources since 1990. It runs based on its own internal fund mobilization, which makes it economically viable and sustainable.

The Grameen Bank (GB) is a shining example of a locally and democratically run CED organization designed to serve the poor people by being run by them. GB is responsive to the people and engages with them on regular bases which are all features of good Ced meaning emphasis on community values. Poor women organize independent associations to receive loans from GB. Borrowers receive loans and save money, repay loans individually and collectively participate in the local association or center weekly meeting. They receive loans from the bank and run their businesses in their locality. They earn money and gradually create personal and collective (community) assets. Every year GB officials, at all levels, face an election. This process of electing a leader helps to develop democratic norms. This system facilitates networking among group members of GB especially poor women. All center chiefs and group chairmen of GB gather at a weekly meeting organized by each center where they discuss and exchange new strategies and concerns. As part of the weekly and monthly meetings center members discuss their status of the business, family matters, community problems, children's education, health and other social agenda. In this way GB borrowers perform both community development and community economic development activities in which GB officials act as a catalysts and help them to reach their goals eradicating of poverty and to empower them in their communities.

Grameen Bank is one of the few community economic development organizations in Bangladesh that includes poor rural women in its cEd program, and provides small loans to rural poor women through group formation and business initiatives. Grameen Bank gives preference to poor female empowerment because it feels that poor women suffer more from poverty than men; and women are much more active to escape poverty than men. Grameen Bank focuses its attention on female community organizing, because it explores and promotes female empowerment both economically and socially. These businesses built up savings that help them find dignified livelihoods by increasing income, providing education to their children, creating material assets and developing social and human capital to overcome their poverty.

One of the prime objectives of the Grameen Bank is to promote female entrepreneurships and to create self-employment. This empowers women economically and socially by increasing their income and creating leadership and networking among them. Now women borrowers of GB become more valuable to their households and they act as catalysts of development in their families. In addition, clients of the GB gain access to better nutrition, housing, and social activities which help them acquire new skills and coping strategies. Women, who are income earners, are empowered to promote their own well-being as well as their families and neighborhoods. This is typical an example of all CED -using economics to improve the community in non-economic ways. Beginning in 2003, Grameen Bank expanded and began to directly tackle homelessness. Approximately 79,000 beggars have already joined the 'Struggling Members Program' setup to deal with their unique situation. $\$ 1.2$ million has been lent to street people so far; of that $\$ 0.53$ million has already been paid off 
(Impact of Grameen Bank on local society (2007) from http://www.rdc.com.au/grameen/impact/htm). The poor commonly live in isolation, trapped in their homes because they have no means to make associations with their neighbors. In this circumstance, GB group-based community banking for the ultra-poor is a milestone initiative for them to make association among them and earn income for their livelihood using micro-business model. The objective of microfinance and the aims of Grameen Bank are to create an environment under which poor people can develop the confidence to survive on their own. Again, this is quintessential ceD. Although Boothroyd \& Davis (1993) says," the limitation of ceD is that it is out of step with the mainstream attachment to unlimited growth" (p.235); however, GB activities contributed to Bangladesh poverty eradication with wide scale.

Although there are critics of CED approach, arguing that it is out of step with the mainstream economy and certain political ideologies, Grameen Bank succeeds in contributing to both the local and the national economy in Bangladesh. In 1998, the World Bank found that extreme poverty among GB borrowers in Bangladesh was cut by over $70 \%$ making Grameen micro finance a powerful tool in combating poverty and female empowerment. Many borrowers of GB are progressing as smart and sustainable business people. The resulting businesses are closely tied into the local neighborhoods, providing an opportunity for development for all the members of the community. Landless women are directed, by the bank, to setup their facilities, relying on the local market and focusing on building strong bonds with the community (bridging bonds among poor people in the community) and other members of the bank. This promotes a sense of responsibility among the members as well as local entrepreneurships, self-employment and a steady flow of income. It reduces dependence on external investments and outside decision making for the family and for the community. The community itself manages its own resources in the tradition of CED.

The Grameen Bank community development program does not only maximize local economic activity in the locality but also creates the kind of social and emotional environment in which people connect with each other to strengthen mutual aid norms, values, customs and practices through GB landless women associations. Social cohesion and solidarity among them crystallizes through making associations. The borrowers of GB discuss their business problems, family problems, and other social problem and how to solve them, and exchange business ideas. This is the theme of community economic development where "CED organizations help to enhance local initiatives that are proactive economic and servicing ventures that invite energetic commitments in the community" (Burman, 1996, p. 139).

Moreover, Grameen Bank is a community economic development scheme in the sense that landless poor women organize themselves in the center, develop leadership qualities, are involved in decision making process, resolve problems through mutual dialogues for improvement of their lifestyle, enhance their children's education and health. These poor women help other poor people and work with them for their development. The borrowers of GB are working together towards improving their hygiene and sanitation in their village, resolve neighborhood conflicts, violence, and dowry problems, develop their voting behaviors, and participate in other human rights issues. They involve themselves in public awareness and act for their class consciousness and social uplift. They become interconnected with each other. Today, they are no longer socially isolated rather they interconnected with their community people.

In addition, GB members are involved in CED activities as it is a place and tool for them for involvement in business for income generation. They use their credit for home-based businesses and or local businesses. They are not involved in distance businesses. Therefore, all their activities create an impact on local businesses and local economy. Poor people now play a collective role in local economic development, which is the impact of Grameen Bank group-based community banking in the villages in Bangladesh.

The Grameen Bank actively provides more than just a source of money to the poor in Bangladesh. It provides help with socio-economic development and simply with the skills of life. Grameen Bank teaches its clients signing their names, basic hygiene, nutrition, family planning and motivates borrowers growing vegetables, animal husbandry, and profitable ways of investment. It assists borrowers to develop their business 
marketing strategies and cope with disasters. Grameen sixteen decisions create borrowers' attention to take care of their children, collective duties and responsibilities as citizens; learns people on how to develop healthy social values, campaign for effective anti-dowry debates and disputes and other such feelings. At the beginning of group trainings, borrowers are organized into small homogeneous groups. Such training facilitates group solidarity as well as participatory interaction among GB group members in their community. Organizing the borrowers into primary groups and associations has been the building blocks of GB's operating system. Emphasis from the very outset is to organizationally strengthen the Grameen client so that they can acquire the capacity for business planning and implementing CED theme at the micro level development decisions.

Grameen community organizing activities include economic activities through micro financing and businesses to increase their income, developing their businesses along with improving social status. GB staffs interactions with its borrowers on regular basis is enhancing borrowers local economic activities; this two way communications are focusing on developing the local poor women communities, empowering local citizens and fostering community control and management. GB is free from bureaucracy. Rather, its officials and clients are like mutual partners in the businesses because loan repayments depend on their mutual goodwill and responsibilities. The bank constantly monitoring and adjusts its policies from grassroots feedback. Therefore, it can be called a community economic development process for the poor that empowers GB women borrowers' family space and public space development in their community. Different types of clients' workshops at the grass root level, organized by GB, help them to develop socially, while adding to human capital.

Grameen Bank breaks the traditional office-based and mortgaged-based loan financing system. For example, the bank goes to people's houses. Loans are delivered to poor women without collateral and loans are collected from their doorsteps. The borrowers need not come to the branch, to collect or repay their loans. They do not incur any extra expenditure to get loans. So the GB borrowers appreciate the Bank's economic and social responsibilities concerning their well-being, and reciprocate with a satisfactory performance in their own interest.

\section{Problems with Grameen Bank}

Grameen Bank operates and provides loans to poor people with a $20 \%$ interest rate. Although GB is a non-governmental organization (NGOs), it is operating much like other commercial banks with the aim of profit. In 2005 , GB made a profit of US\$680,000. Although it is an example of totally self-reliant poverty eradication initiative, its interest rate is the same as loans given to much richer people. Although there have been many success stories of women borrowers of GB who have been emancipated through Grameen micro-credit, Robin Isserles (2003) cautions that many women are still dominated by their husbands and they do not actually enjoy the benefits from their financial gains or loan investments. In many cases, their husbands take the credit, and use the money to their own advantage (Rouf, 2011). Since patriarchy is still dominant in Bangladesh it results in the exploitation of borrowers' rights, choices and voice. Grameen Bank borrowers are highly renowned for their smooth repayment of loans, before they are overdue. High repayment rates always do not indicate high efficiency and quality of women's lives. Isserales, in his study mentions, that $57 \%$ of women saw a rise of verbal aggression after they received loans from their households. 16\% experienced verbal and physical abuse from their husbands if they (women borrowers) refused to hand over the money to their husbands (Isserales, p. 49).

\section{Recommendations and Conclusion}

Government support to NGOs, micro financing and female entrepreneurship can mentor the bottom $50 \%$ of the disadvantaged women and empower them economically, socially and politically in the society both collectively and independently. In addition, national strategies are needed in Bangladesh for other micro financing institutions (MFIs) to improve and make easy micro financing and savings systems available to disadvantaged women. There is a lack of funding for women centered initiatives and CED activities as well as heavy administrative costs which burden CED clients. Therefore, NGOs need some subsidies to cover the 
organizational overhead costs so that clients should not be required to cover those costs. Advocacy on public subsidy to CED is important for a certain period until NGOs can reach a sustainable situation.

It should not seek community development through charity because charity destroys people's initiatives. Burman (1996) rightly says that charities are offensive as they organize the poor in the best way to serve their way of helping (p. 149). Micro financing economic institutions, business promotion institutions and business training institutions both at local and national level should be organized and tailored and linked with the community to promote cooperation among beneficial rather than competition. But public national organizations should not be coercive to CED NGOs.

Bangladesh Rural Development Board's (BRDB) many cooperatives are running where both men and women are members of the same cooperative. Many cooperatives in many countries are also running same way where men and women belong to one cooperative. However, women can get more benefits if CED cooperatives are formed exclusively for women, where they can help each other, feel free to organize, discuss problems, make decisions and exchange ideas without male dominance.

Micro financing institutions (MFIs) and the number of their clients are increasing all over the world. For example, in 2011, more than 150 million and in 2004, more than 66 million of the world's poorest people, of whom $83 \%$ of them women, received small loans to start or expand small businesses compared to 7.6 million in 1997 (Microcredit Summit 2011 and Results Canada Action Sheet, September 2006). In Bangladesh, Grameen Bank's contribution to Bangladesh socio-economic development proves that they contribute to small enterprises, and to eradicate poverty locally. From the above discussion and analysis, it is found that Grameen Bank has implemented Boothroyd and Davis's three approaches to community economic development (CED) theme. Canadian CED organizations and government organizations can take lessons from Bangladesh MFIs and mentor the CED NGOs to promote micro-financing in Canada for revitalizing marginalized people local economy and to empower the bottom $50 \%$ of the disadvantaged women in Canada and move forward to eradicate their poverty.

\section{References}

Boothroyd, P., \& Davis, H. (1993). Community economic development: Three approaches. Journal of Planning Education and Research, 12, 230-240. http://dx.doi.org/10.1177/0739456X9301200307

Burman, P. (1996). Poverty's bonds- power and agency in the social relations of welfare. Toronto: Thompson Educational Publishing, Inc.

Calmeadow Foundation. (2005). Annual report 2005. Toronto: Calmaedow Foundation.

Cheston, S., \& Kuhn, L. (2002). Empowering women through microfinance. In S. Daley-Harris (Ed.), Pathways out of poverty: Innovations in micro-finance for the poorest families (pp. 167-228). Blomington: Kumarian Press Inc.

Christension, J., Fendley, K., \& Robinson, J. (1994). Community development. In J. A. Christenson \& J. W. Robinson (Eds.), Community development perspective (pp. 3-25). Ames, Iowa: Iowa State University.

CIDA. (2001). Human rights report. Dhaka: CIDA.

Coady International Institute. (2015). Themes. Retrieved from http://WWW.coady.stfx.ca

Cruikshank, B. (1994). The will to empower: Technologies of citizenship and the war on poverty. Socialist Review, 23(4), 29-55.

Grameen Bank (2015). Impact of Grameen Bank on local society. Retrieved from http://www.rdc.com.au/grameen/impact/htm

Grameen Dialogue. (2006). SME and microcredit. Newsletter \#63, April 2006. Dhaka: Grameen Trust.

Gramren Bank Updates. (2014). Grameen Bank at a glance. Dhaka: Grameen Bank.

Hick, S. (2004) Social welfare in Canada-understanding income security. Thomson Educational Publishing, Inc, Toronto.

Human Right Report. (2013). Executive summary, Bangladesh. Dhaka: Bangladesh Manobadhikar Samonnoy Parishad (BMSP). 
Eradication of poverty through community economic development using micro financing

Isserles, R. G. (2003). Microcredit: The rhetoric of empowerment, the reality of development as usual. Women's Studies Quarterly, 3(4), pp. 38-57

Kabeer, N. (1983). Minus lives-Women in Bangladesh. Dhaka: University press.

Kretzmann, J. P., \& McKnight J. L. (1993). Building communities from the inside out. Chicago: ACTA Publications.

Lee, B. (1999). Pragmatics of community organization. Mississauga: Common Act Press.

Lotz., J. (1987). Community development- A short history. Journal of Community Development, May/June, 40-46.

Rouf, K. A. (2011). Grameen Bank women borrowers familial and community relationships development in patriarchal Bangladesh. International Journal of Research Studies in Psychology, 1(1), 17-26. http://dx.doi.org/10.5861/ijrsp.2012.v1i1.11

Schaffer, R., Deller, S., \& Marcouiller, D. (2004). Community economics: linking theory and practice. Iowa: Iowa State University Press.

Shragge, E. (1997). Community economic development-in search of empowerment. Montreal: Black Rose Books.

South Asian Foundation (2014). Bangladesh statistical profile. Retrieved on from http://www.southasiafoundation.org/saf/bngladesh/banglastats.asp

Wong, W. A. (2002). The poor women- a critical analysis of Asian theology and contemporary Chinese fiction by women. New York: Peter Lang.

World Bank. (2010). World development report. Washington DC: World Bank

Yunus, M. (2007). Creating a world without poverty. New York: BBS Public Affairs. 
Rouf, K. A. 